\title{
DRAMATYCZNE LOSY KSIĘGOZBIORÓW KOŚCIELNYCH W POLUDNIOWYCH GUBERNIACH KRÓLESTWA POLSKIEGO W XIX WIEKU W ŚWIETLE OBECNEGO ZASOBU STARYCH DRUKÓW BIBLIOTEKI WSD W PLOCKU ${ }^{1}$
}

W związku z przeprowadzoną w Królestwie Polskim na mocy dekretu z dnia 17 IV 1819 r. kasatą zakonów, działająca pod przewodnictwem Ministra Komisji Wyznań Religijnych i Oświecenia Publicznego, Stanisława Kostki - Potockiego, Komisja, wyraziła swoje daleko idące zainteresowanie bibliotekami poklasztornymi i ich bogatymi zasobami. Jeszcze w maju 1819 r. Komisja wydała polecenie utworzonym przez siebie komisjom wojewódzkim, aby natychmiast przystapiły do opieczętowania na swoim terenie bibliotek kasowanych klasztorów i nadesłały w ciagu dwudziestu dni katalogi książek, jakie się w nich znajdują2. W dalszej kolejności Komisja wydelegowała Samuela Bogumiła Lindego, sprawującego wówczas funkcję dyrektora głównego Biblioteki Publicznej w Warszawie do obejrzenia bibliotek likwidowanych wówczas klasztorów i wyłączenia najciekawszych i najcenniejszych książek, które uzna za potrzebne do ,zasilenia zasobu nowopowstałej Biblioteki Warszawskiej. Dysponując specjalnym upoważnieniem wydanym $11 \mathrm{~V} 1819 \mathrm{r}$. przez Stanisława Kostkę-Potockiego, Linde miał pełnomocnictwa w których zawarty był również apel do przełożonych zakonnych, aby ułatwili mu prace penetracyjne w podległych sobie klasztorach i nie przeszkadzali w wypełnianiu nałożonych nań obowiązków ${ }^{3}$. Warto tutaj podkreślić fakt, iż Linde był doskonale przygotowany do czekającej go misji penetracji blibliotek po skasowanych klasztorach. Wcześniej

${ }^{1}$ Temat zasygnalizowany w tytule zasadniczo dotyczy dwóch guberni: radomskiej i lubelskiej. Należy zaznaczyć, że w Królestwie Polskim do 7 III 1837 r. istniały województwa. Podział ten nie miał swego odpowiednika w zaborze pruskim i austriackim. Por. P. P. Gach, Struktury i działalność duszpasterska zakonów męskich na ziemiach dawnej rzeczpospolitej i Ślaska w latach 1773-1918, Lublin 1999, s. 81.

2 M. Łodyński, Materiały do dziejów państwowej polityki bibliotecznej $w$ Księstwie Warszawskim i Królestwie Polskim 1807-1831, Wrocław 1958, s. 31; P. P. Gach, Mienie polskich zakonów i jego losy w XIX wieku, Rzym 1979, s. 11.

${ }^{3}$ M. Łodyński, Materiały do dziejów państwowej polityki bibliotecznej, s. 32. 
bowiem jako bibliotekarz Jerzego Maksymiliana Ossolińskiego w latach 1794-1803 „przeglądną”” na jego polecenie wiele bibliotek klasztornych na terenie zaboru austriackiego, przywożąc swemu chlebodawcy znakomite i cenne dzieła $\mathrm{z}$ tychże bibliotek. Bez watpienia doświadczenie zdobyte w „służbie książki" u Ossolińskiego okazało się bardzo przydatne w jego dalszej pracy i realizacji nałożonych zadań przez Komisję Wyznań Religijnych i Oświecenia Publicznego ${ }^{4}$. W ciagu 114 dni Samuel Bogumił Linde zwizytował zasoby 48 starych bibliotek klasztornych, dodatkowo zaś zbiory z ziem ówczesnego województwa lubelskiego, penetrował kustosz Biblioteki Publicznej w Warszawie - Wiktor Skarbek. Zaledwie w ciągu czterech miesięcy (od września 1819 r.) zrewidowano kolejno biblioteki klasztorne w województwach: mazowieckim, płockim, kaliskim, krakowskim i sandomierskim, w tym jak zaznaczono było łącznie 48 bibliotek zakonnych, 15 kolegiackich i dwie parafialne.

Po wstępnym wyselekcjonowaniu księgozbiorów klasztornych, opieczętowaniu, załadowaniu do skrzyń i beczek, księgi odesłane zostały do zorganizowanych specjalnie do tego celu składów znajdujących się w miejscowościach usytuowanych nad rzekami spławnymi: Hebdowie, Zawichoście, Solcu, Sieciechowie, Płocku i Włocławku (nad Wisła) i Sulejowie nad Pilicą ${ }^{5}$. Rozproszeniu uległy stare biblioteki cystersów w Koprzywnicy, Wąchocku, Jędrzejowie i Sulejowie; benedyktynów w Świętym Krzyżu i Sieciechowie; bożogrobców w Miechowie; paulinów w Beszowej, Brdowie, Łęszycach, Oporowie, Wielgomłynach, Pińczowie; dominikanów w Klimontowie, Gidlach, Sandomierzu; kamedułów w Rytwianach i Szańcu; reformatów w Sandomierzu, Pilicy, Wieluniu i Radomiu; bernardynów w Opatowie, Piotrkowie i Przyrowie; kanoników regularnych laterańskich w Mstowie; norbertanów w Hebdowie Witowie. Nadto księgozbiory żeńskich zgromadzeń zakonnych: benedyktynek w Sandomierzu i Jarosławiu; norbertanek w Busku i Imbramowicach; karmelitanek bosych w Krakowie ${ }^{6}$.

W pierwszej niejako fazie wywozu księgozbiorów klasztornych przez Lindego w 1819 r. do nowoutworzonej Biblioteki Publicznej w Warszawie, zakony, a w ich obrębie klasztory utraciły swoje niemal całe księgozbiory gromadzone przez wieki. I tak m. in. benedyktyni z klasztoru na Łysej Górze - 4400 ksiąg - jak odnotował S.B. Linde ,[...] z biblioteki świętokrzyskiej na Łysej Górze zabrałem sztuk książek 4.400, te w dwnaście pak a sześć beczek zbożowych zapakowawszy odesłałem najętym furmanem do Zawichosta, by stamtąd Wisłą spokojnie udały się do Warszawy"; benedyktyni z Sieciechowa - 3055 woluminów, zapakowa-

${ }^{4}$ O. Błażejewicz, Samuel Bogumił Linde. Bibliotekarz i bibliograf, Wrocław 1975, s. 98-103; P. P. Gach, Mienie polskich zakonów i jego losy w XIX wieku, s. 11-12.

${ }^{5}$ P. P. Gach, Mienie polskich zakonów i jego losy w XIX wieku, s. 11-12.

${ }^{6}$ P. P. Gach, Mienie polskich zakonów i jego losy w XIX wieku, s. 17; Zbiory Polonijne Biblioteki Uniwersyteckiej $w$ Warszawie $i$ wybranych Bibliotek Instytutowych Uniwersytetu Warszawskiego, Warszawa 1999, s. 24-25. Informacje w tekście uzupełnione zostały w oparciu oproweniencje ksiąg pochodzących ze skasowanych klasztorów z terenów południowych guberni Królestwa Polskiego, które aktualnie przechowuje Biblioteka WSD w Płocku.

${ }^{7}$ M. Łodyński, Materiały do dziejów państwowej polityki bibliotecznej, s. 54-56 
nych w 13 pak $^{8}$; benedyktynki z Sandomierza - 102 woluminy, tu zanotował Linde ,[...] dnia 25 sierpnia wyruszyłem z niejakim niebezpieczeństwem dla wylewu Wisty a zatem przez wielkie i głębokie brody do Sandomierza. Tam u panien benedyktynek zdobycz nie była ani wielka ani ważna, tylko 102 sztuki zabrałem, między któremi Stanisława Grochowskiem wierszem w pięknym egzemplarzu", bożogrobcy z Miechowa - 4677 woluminów. Wytrawny książkołap Linde z pełną satysfakcją odnotował ,[...] biblioteka miechowska, chociaż przez lubowników, wędrowników i okoliczności czasowe dość była nadwyrężona i jest atoli tak liczną, żem po trzech dniach dopiero ukończył jej przejrzenie" "10; cystersi z opactwa w Koprzywnicy - 2572 woluminy ${ }^{11}$; cystersi z Sulejowa - 2312. Linde odnotował ,[...] już Sulejów wzięty, niewolnika rozmaitego stopnia jest 2312, te chociaż to wielka nieprzyzwoitość, lecz bieda przymusza zamknąłem w 66 beczkach nowych, właściwie przeznaczonych na wapno sulejowskie" ${ }^{12}$; cystersi z Wąchocka - $2438^{13}$; cystersi z Jędrzejowa - 605 woluminów. Liczba zabranych ksiąg z Jędrzejowa była tak mała, gdyż tamtejsza biblioteka prawie całkowicie uległa zniszczeniu podczas pożaru klasztoru w 1800 r. ${ }^{14}$; kameduli z Rytwian - 475 woluminów ${ }^{15}$, kameduli z Szańca - 340 woluminów ${ }^{16}$; kanonicy regularni z Mstowa $-965^{17}$; paulini z Beszowej - 540 woluminów. Według relacji Lindego klasztor wraz z biblioteką były w opłakanym stanie ,[...] żadna też biblioteka przy rewizji tak mnie nie nudziła jak ta niechlujna beszowska. Książek dosyć, lecz prawie wszystkie w najbiedniejszym stanie; ${ }^{18}$ paulini z Pińczowa - 340 woluminów „[...J ksiegi nieźle, lecz nic osobliwego”"19; norbertanie z Hebdowa - 1686 woluminów ${ }^{20}$; reformaci z Pilicy - 13 woluminów ,[...] gdyż w samej rzeczy nie było co wziąć" ${ }^{21}$; Jeszcze mniej bo zaledwie pięć woluminów zabrał Linde z klasztoru reformatów w Sandomierzu ${ }^{22}$.

Znakomitą charakterystykę losów bibliotek i archiwów zakonnych omawianego okresu zawarł Ludwik Łętowski ${ }^{23}$, ,.... Dawna Polska miała co katedra,

\footnotetext{
${ }^{8}$ Tamże, s. 71-72.

${ }^{9}$ Tamże, s. 62, 71-75.

${ }^{10}$ Tamże, s. 58, 74.

${ }^{11}$ Tamże, s. 61, 75 .

12 Tamże, s. 44.

${ }^{13}$ Tamże, s. 53, 69, 75.

${ }^{14}$ Tamże, s. 58,74.

15 Tamże, s. 61, 75.

${ }^{16}$ Tamże, s. 60, 71, 74

${ }^{17}$ Tamże, s. 49, 69, 75.

${ }^{18}$ Tamże, s. 60-61, 71.

${ }^{19}$ Tamże, s. 60.

${ }^{20}$ Tamże, s. 70, 74.

${ }^{21}$ Tamże, s. 58.

${ }^{22}$ Tamże, s. 62.

${ }^{23}$ L. Łętowski (1786-1868), żołnierz, uczestnik kampanii napoleońskiej, od 1818 r. kapłan, proboszcz w Końskich i Stobnicy, kanonik krakowski, członek Senatu Rządzącego Rzeczpospolitej Krakowskiej w latach 1841-1849, wikariusz apostolski, biskup sufragan diecezji krakowko-kieleckiej z tytułem biskupa Jopy, publicysta, literat, pamiętnikarz i bibliofil.
} 
co kolegiata, co klasztor, co opactwo, biblioteki i archiwa, a co kościół to książek po kilkaset. Pamięta się jeszcze na biblioteki: świętokrzyska, miechowska, wąchocka, hebdowska, andrzejowska, sulejowska... Po owym zaborze książek z góry rzucano się $\mathrm{z}$ dół na książki po kościołach jakby one były primi occupantis... Wynoszono wtedy książki, nie jako kradzież, lecz jako zdobycz. Chełpiono się z tych nabytków, lecz bez wstydu na czole. Co najpocieszniejsze to, że nazywano mnichów głupimi, gdy wielu z onych miłośników książek umiało zaledwie odczytać pierwszą kartkę po nich. Czego też nieprzyjaciel nie wywiódł a rząd nie zabral, to rozdrapali swoi" 24 .

Posumowując pierwszy etap kasat zakonów w XIX wieku na terenie Królestwa Polskiego trzeba zaznaczyć, iż skasowano wówczas 29 najbogatszych klasztorów męskich i sześć żeńskich, przejmując całe mienie zakonne (zabudowania klasztorne, gospodarcze, wyposażenie oraz księgozbiory). Miary całkowitego zniszczenia zakonów miały dokonać lata 60 . XIX stulecia.

Ostatnie miesiące $1864 \mathrm{r}$. tj. od października do grudnia tegoż roku uważane są przez polską historiografię za przełomowe w dziejach zakonów w Królestwie Polskim w tym i księgozbiorów. Na podstawie ukazu cara Aleksandra II z dnia 27 X (8 XI) 1864 r., skasowano na terenie Królestwa Polskiego 115 klasztorów męskich i trzy żeńskie. W latach następnych 1865-1866 zamknięto dalszych 14 . Ogółem zniesiono 132 domy zakonne w tym 129 męskich i trzy żeńskie a wśród nich cztery monastery bazylianów unickich. Pozostałe zaś klasztory, stanowiące $20 \%$ z ogólnej liczby istniejących przed kasatą podzielono na tzw. etatowe (25 męskich i dziesięć żeńskich z 14 osobami każdy, jedynie paulinom w Częstochowie przydzielono etat 24 zakonników) oraz klasztory nieetatowe tzn. przeznaczone do całkowitej kasaty z chwilą gdy zakonnicy wymrą i będzie ich mniej niż ośmiu ${ }^{25}$.

W 1864 r. w Królestwie Polskim na terenie guberni lubelskiej było sześć klasztorów bernardynów, cztery reformatów, trzy franciszkanów konwentualnych, sześć dominikanów, po trzy: paulinów, pijarów i augustianów, po jednym: misjonarzy, karmelitów trzewiczkowych, karmelitów bosych, bonifratrów oraz kanoników regularnych laterańskich. Na terenie guberni radomskiej odnotowano w 1864 r. sześć klasztorów reformatów, pięć bernardynów, cztery franciszkanów konwentualnych, trzy dominikanów, po jednym: pijarów, augustianów oraz filipinów-oratorianów. Ogółem w 1864 r. w guberni lubelskiej było 37 domów zakonnych ze znaczącą przewagą bernardynów oraz dominikanów i reformatów, zaś w guberni radomskiej odnotowano 21 domów zakonnych tj. o 16 mniej niż w guberni lubelskiej. Tutaj znacząco w liczbach na plan pierwszy wysuwają się reformaci z sześcioma domami oraz bernardyni z pięcioma ${ }^{26}$. W 1864 r. na terenie

${ }^{24}$ L. Łętowski, Wiadomość krótka o zbiorach książek polskich za naszego wieku: jak i gdzie, u kogo?, ABMK, 6 (1963) s. 359-60.

25 P. P. Gach, Kasaty zakonów na ziemiach dawnej Rzeczpospolitej i Śląska 1773-1914, Lublin 1984, s. 87-113; Tenże, Strutury i działalność duszpasterska zakonów męskich na ziemiach dawnej Rzeczpospolitej i Ślaska w latach 1773 -1914, Lublin 1999, s. 96-102.

${ }^{26}$ P. P. Gach, Strutury i działalność duszpasterska zakonów męskich, s. 103. 
guberni lubelskiej w 37 domach zakonnych było 303 zakonników, zaś w guberni radomskiej - $199^{27}$.

Oficjalnie wśród wymienionych przyczyn tak daleko zakrojonych kasat zakonów - będących faktycznie pretekstem - podano m.in. zbyt małą liczbę zakonników w klasztorach, ich niewłaściwy zarząd dobrami ruchomymi, rozkład życia wewnętrznego i nieprzydatność czy wręcz szkodliwość społeczną. Dnia 20 IX (2 X) 1865 r. skasowano klasztory: filipinów-oratorianów w Studziannej, marianów w Igłówce, bernardynów w Krześlinie i Łukowie ${ }^{28}$. W 1866 r. kasacie uległy dalsze klasztory: bernardynów, marianów, reformatów i kapucynów ${ }^{29}$.

$\mathrm{Na}$ przełomie 1864/1865 r. przystapiono do oszacowania majątków klasztornych, przejętych przez władze carskie. W myśl przepisów i wskazówek spisywano wszelkie dobra ruchome i nieruchome klasztorów, ponadto sporządzano wykazy ksiąg znajdujących się na wyposażeniu zakrystii kościelnej i bibliotece klasztornej. Nie zapomniano też o imiennym spisie duchowieństwa i służby kościelnej. Jak już zaznaczono, komisje przejmujące mienie zakonne w każdym klasztorze opisywały bibliotekę, liczyły książki i przechowywane tam rękopisy. Szczególną uwagę zwracano na piękne i rzadkie oprawy ksiąg mające znaczenie artystyczne (w tym i materialne). Działając zgodnie z otrzymaną instrukcją, likwidatorzy carscy powierzali księgozbiór klasztorny opiece miejscowego proboszcza, wikariusza bądź dziekana. Nadto przepisy dodatkowe towarzyszące ukazowi kasacyjnemu, wyraźnie postanawiały, że biblioteki mają być w tych klasztorach, do których przewieziono wcześniej zakonników. W wielu jednak przypadkach księgozbiory zostały spisane pobieżnie, niedbale, pozostawione w swoich macierzystych klasztorach, całkowicie narażone na zniszczenie i kradzież. Sprawa niszczejących księgozbiorów klasztornych została przedstawiona w 1865 r. przez administratora diecezji warszawskiej P. Rzewuskiego i biskupa sandomierskiego J.M. Juszyńskiego, dyrektorowi Komisji Rządowej Spraw Wewnętrznych - Czerkaskiemu ${ }^{30}$. Zwrócili się oni z prośbą przekazania księgozbiorów po skasowanych klasztorach do Akademii Duchownej w Warszawie (ks. P. Rzewuski) i Seminarium Duchownego w Sandomierzu (bp Juszyński). Zgoda taka została udzielona 5 II (17 II) 1865 r. z zastrzeżeniem „oddać książki w miarę jak będą czynione o nie starania”. Już pod koniec lata 1865 r. do Seminarium sandomierskiego napłynęły księgozbiory ze skasowanych klasztorów diecezji sandomierskiej. Ostatecznie Seminaria Duchowne uznano za najodpowiedniejsze miejsca do przechowywania i użytkowania dawnych bibliotek klasztornych. Najszybciej i najsprawniej akcję przewiezienia ksiag ze skasowanych klasztorów przeprowadzono na terenie diecezji sandomierskiej (1865), włocławskiej (1868), warszawskiej (1869) i płockiej (1870). Do Biblioteki Wyższego Seminarium Duchownego w Płocku, księgi po skasowanych klasztorach $\mathrm{w}$ diecezji sandomierskiej $\mathrm{i}$ innych klasztorach guberni lubelskej

\footnotetext{
${ }^{27}$ Tamże, s. 106.

${ }^{28}$ P. P. Gach, Mienie polskich zakonów i jego losy w XIX wieku, s. 31.

${ }^{29}$ Tamże.

${ }^{30}$ Tamże, s. 36.
} 
i radomskiej, przechowywane w semianarium sandomierskim, trafiły dopiero po $1945 \mathrm{r}$.

I tak z druków XVI-wiecznych do zbiorów Biblioteki trafiło: sześć woluminów z biblioteki klasztoru bernardynów w Radomiu, jeden wolumin z klasztoru bernardynów z Opatowa, cztery woluminy z klasztoru dominikanów z Klimontowa k. Sandomierza, dwa z klasztoru franciszkanów konwentualnych w Zamościu, jeden z klasztoru reformatów z Lublina, po jednym woluminie z klasztoru jezuitów z Sandomierza i klasztoru pijarów z Radomia.

Spośród druków XVII -wiecznych $\mathrm{z}$ analizowanego terenu $\mathrm{w}$ bibliotece płockiej znalazło się: 15 woluminów z klasztoru benedyktynek w Sandomierzu, sześć woluminów z klasztoru bernardynów z Radomia, po jednym z klasztoru bernardynów z Kazanowa i Opatowa, dwa woluminy z klasztoru cystersów z Wąchocka, jeden z klasztoru cystersów z Jędrzejowa, jeden z klasztoru dominikanów z Klimontowa, osiem z klasztoru franciszkanów konwentualnych z Zamościa, dwa woluminy z klasztoru franciszkanów konwentualnych w Chęcinach, po jednym woluminie z klasztorów kanoników regularnych z Mstowa i Opatowa, 18 woluminów z klasztoru filipinów-oratorianów ze Studziannej, 16 woluminów z klasztoru reformatów z Sandomierza, 13 z klasztoru reformatów z Solca, cztery woluminy $\mathrm{z}$ klasztoru reformatów z Lublina, po jednym z klasztorów reformatów w Pilicy i Pińczowa, siedem woluminów z klasztoru pijarów w Radomiu, dwa z klasztoru bożogrobców z Miechowa i jeden wolumin z klasztoru jezuitów $\mathrm{z}$ Sandomierza.

Z XVIII-wiecznych druków w Bibliotece WSD w Płocku odnotowano: osiem woluminów z klasztoru benedyktynek w Sandomierzu, po cztery z klasztorów bernardynów w Radomiu i Kazanowie, sześć woluminów z klasztoru dominikanów w Klimontowie, pięć z klasztoru franciszkanów konwentualnych z Zamościa, dwa z klasztoru filipinów-oratorianów ze Studziannej, 17 z klasztoru pijarów z Radomia, 21 woluminów z klasztoru reformatów w Solcu, 13 z klasztoru reformatów w Sandomierzu, sześć z klasztoru reformatów w Lublinie, po dwa woluminy z klasztorów reformatów z Kazimierza Dolnego n. Wisłą, Zamościa i Pińczowa, jeden z klasztoru reformatów z Kielc, po jednym z klasztorów cystersów w Wąchocku, Sulejowie oraz klasztoru bożogrobców w Miechowie ${ }^{31}$.

$\mathrm{Z}$ powyższego zestawienia wyraźnie widać, że droga jaką przebywały księgi ze skasowanych klasztorów w XIX i XX wieku była dramatyczna i zawiła. Należy jedynie wyrazić radość, że część ze skasowanych księgozbiorów ocalała dając świadectwo kultury intelektualnej minionych pokoleń zakonników na ziemiach polskich.

${ }^{31}$ Dane te pochodzą z Księgi inwentarzowej zasobu starych druków XVI-XVIII w., Biblioteki WSD w Płocku. Inwentarz sporządzili w latach 2005-2008: ks. Waldemar Graczyk i Jolanta M. Marszalska. 